\title{
Comparative Study between the Electrical Generators Used in Wind Energy Conversion Systems
}

\author{
Mohamed I. Mosaad \\ Electrical and Electronics Engineering Technology Department, \\ Yanbu Industrial College (YIC), Yanbu, Kingdom of Saudi Arabia
}

\begin{abstract}
To keep away from non-renewable fossil energy, clean and green wind energy is one of the sustainable sources in nature that produce the electrical power with no-fossil energy issues. The fastest growing type of renewable energy is the wind energy due to its free availability and environmental problems. Wind energy conversion systems (WECSs) assume a significant part in the new production of electric power from renewable sources. Due to the technical progress in the wind turbine manufacturing, we have many types of wind turbines in use around the world. Many kinds of generators were used in the WECS. In this paper a comparison between three types of generators exploited in WECSs will be introduced. These types are self-excited induction generators (SEIGs), doubly-fed induction generator (DFIGs) and switched reluctance generators (SRGs). The comparison between the generators includes the speed range of operation, fault sensitivity, power ratings and the suitable types of wind turbines used for the three generators, moreover the control techniques applied.
\end{abstract}

Keywords - Wind energy conversion systems, Generators, Self-excited induction generators, switched reluctance generator, doubly-fed induction generator.

\section{INTRODUCTION}

Due to the increasing demand for renewable energy and the gradual departure from fossil fuels, many types of renewable energy sources has appeared recently. All these renewable energy sources depend on converting the sustainable nature energy to electrical energy. From these energies solar energy, hydroelectric energy, biomass, fuel cell and wind energy [1-3]. Wind energy has distinguished from many types of renewable energy due to its high productivity and dependability compared to other types of renewable energy [4]. WE is one of the furthermost efficient renewable energy source that generate electrical power from kinetic energy. The demand for wind energy has increased recently in many countries around the world [1-4]. Different kinds of generators were presented in wind energy conversion systems (WECSs) due to some variations in weather and climate from region to region, and different operating conditions. Like large or small turbines, as well as operation at fixed speed or variable speed.

Self-Excited Induction Generators (SEIGs) [4-5], DoublyFed Induction Generators (DFIGs) [6-7] and Switched Reluctance Generators (SRGs) were used and implemented in many WECS applications [8-9].

To improve performance of WECS and increase the power generated from the WECS some devices were used to interchange active and reactive power with some storage devices as needed based on the variation operating conditions. These devices are called flexible AC transmission systems (FACTS). These devices had received many uses in different power system applications [10-132].
This paper presents a comparative study between three generators (SEIG, DFIG and SRG) used for WECS applications. This comparison includes the speed range of operation, fault sensitivity, ratings, and type of turbine, advantages and disadvantages. The result of this comparison is the decision to choose the right generator for the right turbine.

\section{SELF-EXCITED INDUCTION GENERATOR FOR WECS}

IGs are not self-excited machine without adding some devices to support the magnetic field. In this manner all together to mature the rotating magnetic field, it needs magnetizing current and reactive power support.

IGs get the magnetizing current and reactive power from several sources like the grid in case of grid-connected SEIG or from capacitor banks or some FACTS devices. IG can't operate in off-grid applications because it always requires reactive power from the supply system. However, the selfexcited or isolated IG can operate if a capacitor bank for reactive power supply instead of an AC power supply system was used. A typical configuration of a gridconnected SEIG is in Fig.1.

The role of the capacitor bank is to deliver the reactive power to the IG in addition to load. Some developments in these capacitor based voltage source converters are used to improve the performance like shunt FACTS devices. Many shunt FACTS devices had been implements and used in many WECS. Static Var compensators (SVC) and Static compensator (STATCOM) were used for improving the voltage profile at point of connecting the WECS to the grid [4-5]. These shunt FACTS devices also improve the overall system performance through regulate the injection of the reactive power to the system through disturbances. The interpretation of the need of SEIG for reactive power support and magnetizing is explained through the SEIG magnetizing curve shown in Fig.2.

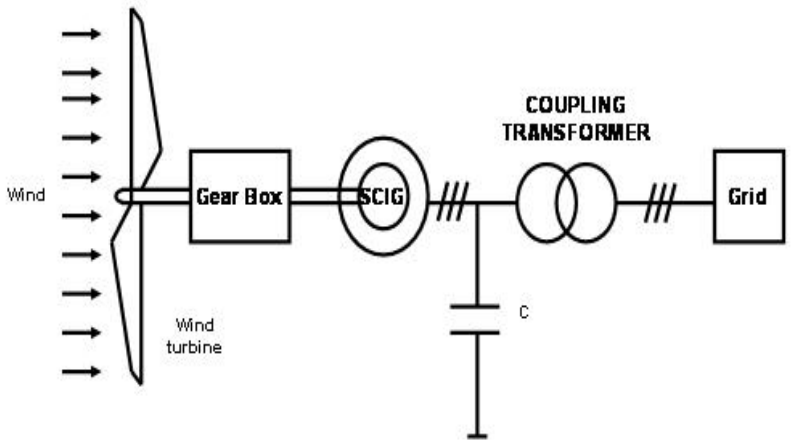


Fig.1: SEIG system

\section{A. Magnetization curve of Induction machine}

Low voltage is generated at (oa), Fig.2 at the stator terminal as the residual magnetism when the rotor speed reaches to the required speed. Because of this voltage, the capacitor current $(\mathrm{ob})$ is generated. The current $(\mathrm{bc})$ produces the current (od) that consequently the voltage (de).

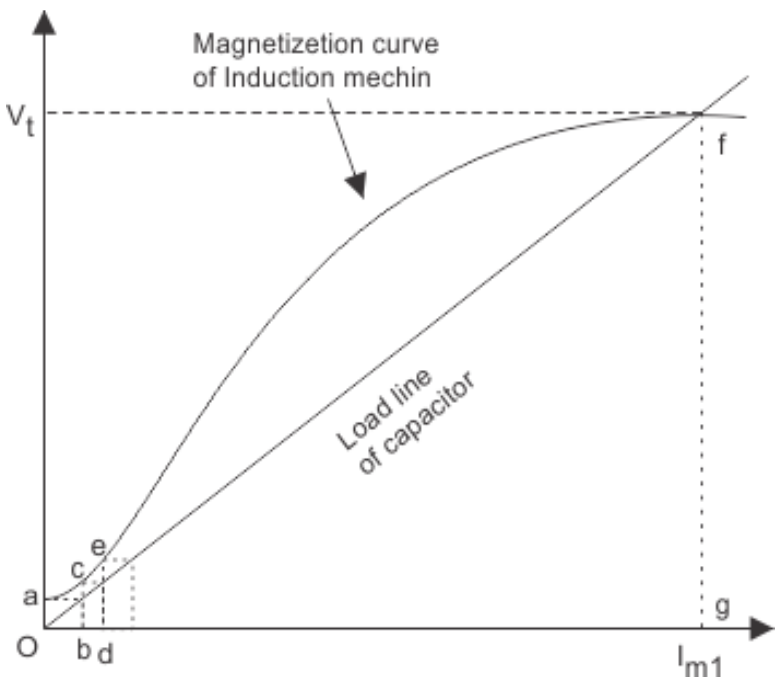

Fig.2: The magnetization curve of SEIG

The growing process of voltage build-up lasts till the saturation curve of the IG meets the capacitor load line at some point, $f$.

The main problem associated with using SEIGs, is the deprived voltage and frequency regulations at changeable loading situations. Any variation in the load impedance legitimately influences the machine excitation. This is on the grounds that the reactive power of the excitation capacitors is shared by both the acceptance machine and the load impedance. Along these lines, the generator's voltage drops when the load impedance is expanded bringing about reduced voltage guideline. On the other hand, the slip of the IG increases with increasing load, resulting in a load dependent frequency, regardless of whether constant prime mover speed [10-12].

\section{B. Effect of Varying the Capacitor}

Increasing the size of the capacitor or increasing the operating frequency moves the operating point on the statorload admittance vertically, thus increasing the imaginary part of the stator load admittance. The increment is balanced mostly by the increment of the magnetizing branch admittance in other words, growing the saturation level. Thus, at any frequency, increasing the size of the capacitor will increase the air-gap flux. As the capacitor increased, the air gap voltage increases. As the air gap voltage increases, the terminal voltage also increases and as a result the output power will be also increases.

\section{DOUBLY-FED INDUCTION GENERATOR FOR WECS}

DFIG is actually wound rotor induction machine which means that both the stator and the rotor have windings. Also slip rings to transfer the power to the rotor. The difference between SEIG and DFIG is that the rotor windings in DFIG is supplied by three-phase power to create $\mathrm{AC}$ current passing through the rotor windings which produces a rotating magnetic field. The rotor coupled with the wind turbine, and as the turbine rotates the rotor will rotate. The changing magnetic field produced by passing the AC current in the rotor windings will rotate as the rotation of the rotor with speed relational to the frequency of the applied AC power to rotor windings. Consequently of the rotating magnetic field of the rotor passes through the stator windings will induce $\mathrm{AC}$ current in stator windings, so power is generated. The synchronous speed of the stator relies on the rotor speed and the frequency of the $\mathrm{AC}$ power of the rotor windings.

Since the rotating magnetic field produced in stator not only rotates due to the rotation of the rotor, but also due to the rotating magnetic field produced by AC current supplied to the rotor windings. We can say that, the rotor speed $\left(\mathrm{n}_{\text {rotor }}\right)$ and frequency of $\mathrm{AC}$ current given to rotor windings ( $\left.f_{\text {rotor }}\right)$ can determine the speed of the stator rotating magnetic field $\left(\mathrm{n}_{\text {stator }}\right)$ and thus the frequency of the stator $\left(\mathrm{f}_{\text {stator }}\right)$.

If the rotation of the magnetic field of the rotor in the same direction of the rotor rotation the stator frequency can be calculated as

$$
f \text { stator }=\frac{n \text { rotor } * N \text { poles }}{120}+f \text { Rotor }
$$

If the rotation of the magnetic field of the rotor is opposite to the direction of the rotor rotation the stator frequency can be calculated as

$$
f \text { stator }=\frac{n \text { rotor } * N \text { poles }}{120}-f \text { Rotor }
$$

\section{A. Operation of DFIG in WECS}

As shown in the Fig.3, the rotor windings are tied to the grid through the slip rings and back to back voltage-source converters. These converters are used to control both rotor and grid currents. By using this converter the frequency of the rotor cannot be the same of the frequency of the grid which is 60 or $50 \mathrm{~Hz}$.

The basic requirement to generate electrical power by using wind turbines is to produce $\mathrm{AC}$ sine wave of constant frequency which is equal to the grid frequency regardless to the wind speed. Which means the power generated frequency have to be constant irrespective to the variations of the motor speed. To attain this, the power frequency of the rotor must be adjusted. The rotor frequency should be varied to make the stator frequency equal to the grid frequency.

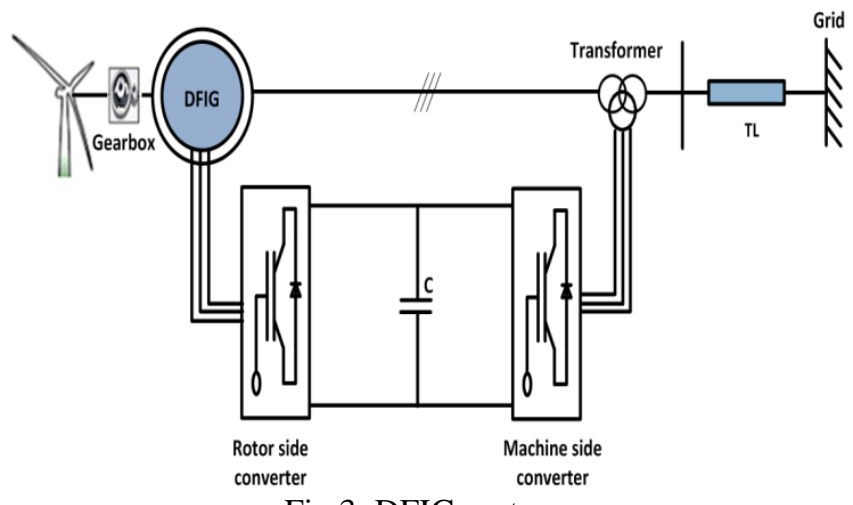

Fig.3: DFIG system 


\section{B. Back To Back Converters}

The back to back converters consist of two parts- a grid side converter and machine side converter with capacitor between them. They are connected as a feedback loop of the system. The machine side converter is used to governor the active and reactive power supplied to the machine. The grid side converter is used to secure the unity power factor operation by drawing the reactive power from the grid equal to zero. The capacitor which is located between the two converters plays as an energy storage. This back to back controller offers constant frequency and constant voltage output regardless to the variable frequency and voltage.

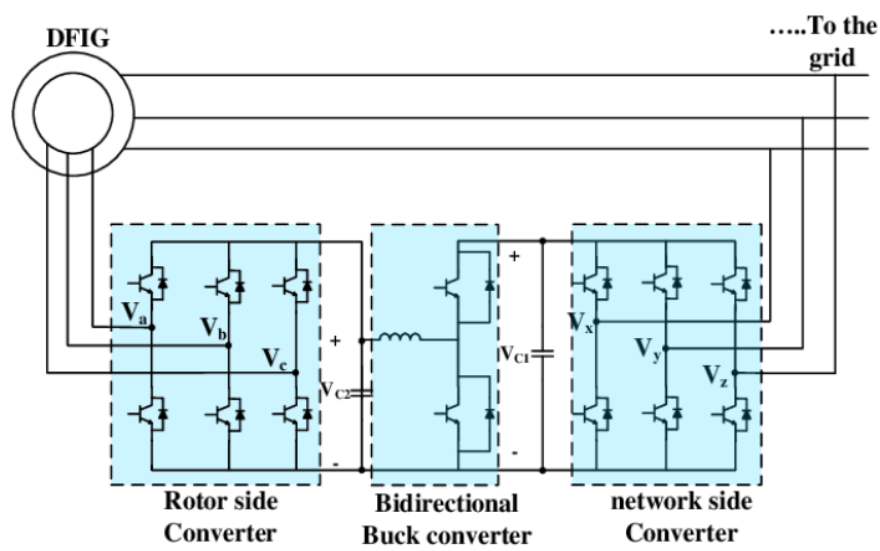

Fig.4: Back to Back converter of DFIG system

Many control techniques were presented to improve the performance of DFIG-WECS. These techniques are based on regulating the active and reactive power flow between the generator and the utility during abnormal operating conditions. These control techniques may be achieved by regulating the grid and machine converters themselves or by adding some FACTS devices. On the other hand some control techniques were presented to regulate the DC link voltage.

Unified power flow controller (UPFC), one of the combined series-shunt FACTS devices was used to regulate the reactive power flow between the utility and DFIG-WECS and consequently improve the system performance [12]. Another technique was presented for regulating the DC link voltage by adding superconductor as presented in [11].

\section{SWITCHED-RELUCTANCE GENERATOR FOR WECS}

SRG is an electromechanical energy converter converting mechanical energy into electrical one. SRG has stator and rotor with no windings and nor permanent magnets in the rotor. For SRG action, the excitation part that is regulated in agreement with the rotor angle position is needed. When the poles are repelled enough, the phase current by diodes is charging the DC link capacitor. The excitation current is changed to the next phase by using power electronic switches depending of the voltage of the DC link capacitor. Consequently the SRG produces the power with stable DC voltages [8-9].

\section{A. Operation of SRG in WECS}

In electrical drives with changeable reluctance, the torque is dependent of the rotor's angular position. The process of the machine as a generator is attained by exciting the stator's windings while the rotor's salient poles are away from their position at to the rotating motion of the prime mover. The SR machine is characterized by a different mode of controlling its phase current, because that utilize power electronic converter used operates in a manner to make the machine phase-currents are imposed for specific positions of the rotor [8].

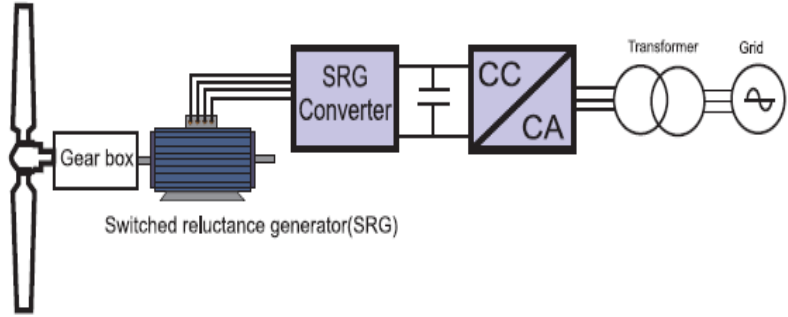

Fig.5: SRG system

Using a typical topology of the converter utilized in SRM drives such that providing a greater flexibility concerning its adjustment and well fault acceptance. SRG along with the two converters used is shown in Fig.6.

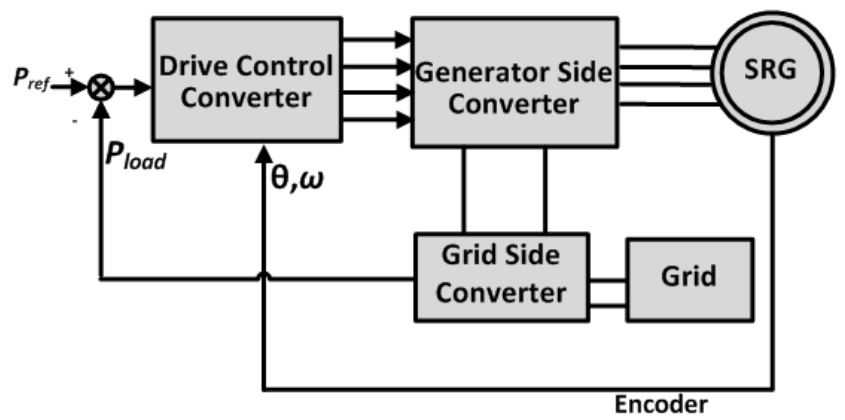

Fig.6 Switched reluctance generator with two converters

\section{B. SRG Converters}

The grid side converter is controlling the charging and discharging periods of the generator. While the generator side converter is used for connecting the generator to the grid by converting the DC of the SRG to AC. The excitation performed through one phase of the generator is given to the excitation voltage, that leads to flowing of current in the winding of this rising phase. In generating the current through the Switched reluctance generator phase to the load. In each period of the excitation, voltage bus converts energy to the magnetic field of the conforming phase and this energy flows to the load together with the share resulting from the conversion of mechanical energy into electrical. Usually the initial excitation is provided by an external source for example battery until the capacitor is charged. This pass the same capacitor exciting the phases when the external source is dropped [9].

The SRG control is consummated through governing the converter switches. The amount for controlling the generation of switched reluctance generator is the period of excitation, the operating speed and excitation voltage. . In case of load change to maintain the generated voltage. This control is used for power generation connected to the grid. In this case the SRG is not tied legitimately with the load, however with another converter that is liable for sending the generated power to the utility. 


\section{FIXED AND VARIABLE SPEED WIND TURBINES}

The significant factor that influences the feasibility of the WECS is the measure of wind vitality accessible at potential locales Anyway the absolute yearly vitality yield and the planning of power creation rely upon the WECS structure for which changeable and consistent shaft speeds tasks are two significant prospects. It very well may be indicated that the activity method of the subsequent framework influences the absolute yearly vitality yield and henceforth the expense of age as it were. Large size wind turbines divided into two types according the behavior of the variation of winds speed which are constant and mutable speed wind turbines.

\section{A. SEIG in Fixed Speed Wind Turbines}

The greater part of the current huge frameworks in activity are constructed or wanted to run at steady speed in synchronization with the utility network. As of not long ago, this has typically been accomplished by using mechanical control means, for example, blade pitch angle control. The SEIGs are coupled with fixed speed wind turbine through a gear box and the stator windings of the generator are tied to the grid through a transformer as in Fig.1.

A cage rotor IG takes magnetizing current as soon as tied to the utility thereby reducing stator power factor. Under low wind conditions, when the active power generation is low, the machine mainly draws reactive power from the grid and the stator power factor is extremely poor. The lagging reactive power is waged by tying capacitor banks across the line. Subject to the active power generation, these capacitors are either cut in or cut-out to regulate the average power factor of the generator between 0.95 and 1. But the arbitrary switching of the capacitor banks gives rise to undesirable transients in the line currents and voltages. In a network, where many such machines are introduced, these capacitive exchanging can cause extreme over voltage issues. The constant speed system even though, obviously straightforward and dependable, seriously restricts the amount of intensity created and has a few related drawbacks which need key courtesy.

\section{B. DFIG in Variable Speed Wind Turbines}

In the ongoing past, the additional expense and multifaceted nature of a variable speed generator as well as a variable proportion transmission, and basic elements difficulties of having to work with wide range of speeds have been considered as the main drawbacks in variable speed systems. It is currently conceivable to get fixed voltage and frequency operation with variable shaft speed turbines at high power levels, utilizing static power converters. The rotor speed of wind turbine is allowed to vary. This precludes the use of asynchronous and synchronous generators. The doubly fed generator comes in this case. The output voltage and frequency are maintained at constant value which is the value of the grid no matter the wind speed. To achieve this constant voltage and frequency, back to back converters to fed AC current to the rotor of generator by adjusting the voltage and frequency. This allows operating without sudden torque variations to the wind turbine and reduces the stress on the mechanical components.
To summarize and facilitate the selection of the type of generator required for a particular WECS. Table I. shows a performance comparison between the three types of generators that can be used in WECS in term of speed range, power ratings, fault sensitivity, usage of turbine can be used for, advantages and disadvantages.

TABLE I. COMPARISON BETWEEN THE TYPES OF GENERATORS, [4-9].

\begin{tabular}{|c|c|c|c|}
\hline \multirow{2}{*}{ Performance } & \multicolumn{3}{|c|}{ Machine Types } \\
\hline & DFIG & $S R G$ & SEIG \\
\hline $\begin{array}{l}\text { Speed range } \\
\text { of operation }\end{array}$ & $\begin{array}{l}\text { Wide speed scope. } \\
\text { Ability for operation } \\
\text { at low speed. }\end{array}$ & $\begin{array}{l}\text { Wide speed } \\
\text { range. } \\
\text { can operate at } \\
\text { high speed }\end{array}$ & $\begin{array}{l}\text { Narrow speed } \\
\text { range }\end{array}$ \\
\hline $\begin{array}{c}\text { Fault } \\
\text { Sensitivity }\end{array}$ & More sensitive & Less sensitive & More sensitive \\
\hline $\begin{array}{l}\text { Types of } \\
\text { Turbines }\end{array}$ & $\begin{array}{l}\text { Large size variable } \\
\text { speed Wind Turbine }\end{array}$ & $\begin{array}{l}\text { Small to } \\
\text { Medium size } \\
\text { variable speed } \\
\text { Wind Turbine }\end{array}$ & $\begin{array}{l}\text { Large size fixed } \\
\text { speed Wind } \\
\text { Turbine }\end{array}$ \\
\hline Ratings & $3.6 \mathrm{MW}$ & $500 \mathrm{KW}$ & Below 1.5MW \\
\hline Advantages & $\begin{array}{l}\text { The power will } \\
\text { generate even with } \\
\text { low speed. } \\
\text { The converter of } \\
\text { the system take } \\
\text { only } 20 \% \text { to } 30 \% \\
\text { of the generated } \\
\text { power, so the size } \\
\text { and the cost will } \\
\text { reduce }\end{array}$ & $\begin{array}{l}\text { simple } \\
\text { control } \\
\text {. low inertia }\end{array}$ & $\begin{array}{l}\text { Relatively } \\
\text { cheaper } \\
\text {. It has robust } \\
\text { construction } \\
\text { requiring less } \\
\text { maintenance }\end{array}$ \\
\hline Disadvantage & $\begin{array}{l}\text { Heavy } \\
\text { maintenance work } \\
\text { for rotor slip rings } \\
\text { with high cost. } \\
\text { In case of } \\
\text { disturbance of the } \\
\text { grid, the ride } \\
\text { through } \\
\text { requirement make } \\
\text { DFIG control very } \\
\text { complex }\end{array}$ & $\begin{array}{l}\text { High torque } \\
\text { ripple. } \\
\text { Acoustic } \\
\text { noise } \\
\text { generation. }\end{array}$ & $\begin{array}{l}\text { The measure } \\
\text { of reactive } \\
\text { power used to } \\
\text { run these sorts } \\
\text { of generator } \\
\text { required is } \\
\text { extremely } \\
\text { tremendous. }\end{array}$ \\
\hline
\end{tabular}

\section{CONCLUSION}

This paper presents a comparison between three types of electrical generators (SEIG, DFIG and SRG) used for wind energy conversion systems applications. This comparison aims at facilitate the selection of the generator for certain application. The comparison includes the operation of the generated under constant or variable speed along with the range of speed, power ratings and voltage sensitivity. SEIG has high ratings and it is more simple than DFIG and SRG, however voltage sensitivity to faults and narrow range of speed operation. DFIG with the developments of power electronics devices can operate at large range of speed with improvement the voltage sensitivity if properly controlled. SRG with its simple construction has find many applications in WECS with increasable rate up to $1.5 \mathrm{MW}$.

\section{REFERENCES}

[1] M. Osama abed el-Raouf, Mohamed I. Mosaad, Mahmoud A. AlAhmar and Fahmy M. El Bendary "MPPT of Hybrid solar-windgrid power generation system" Int. J. Industrial Electronics and Drives-Inderscience Publishers, Vol. 2, No. 4, 2015, pp. 234-241.

[2] M. Osama abed el-Raouf, Mohamed I. Mosaad, Adel Mallawany, Mahmoud A. Al-Ahmar and Fahmy M. El Bendary "MPPT of PVWind-Fuel cell of off-grid Hybrid System for a New Community" 
Twentieth International Middle East Power Systems Conference (MEPCON), 480 - 487, 2018.

[3] Mohamed I.Mosaad, M. Osama Abed El-Raouf, Mahmoud A.AlAhmar, Fahmy M.El Bendary, "Optimal PI Controller of DVR to Enhance the Performance of Hybrid Power System Feeding a Remote Area in Egypt" Sustainable Cities and Society, Volume 47, May 2019, pp.101469-101483.

[4] Mosaad, M.I., Salem, F.: 'Adaptive voltage regulation of self-excited induction generator using FACTS controllers', Int. J. Ind. Electron. Drives, 2014, 1, (4), pp. 219-226

[5] M.A ELhamed Zaki, Mohamed I. Mosaad, Mohamed G. Ashmawy , Abd El Aziz Osman "Power Quality Improvement of WEGCS Using STATCOM Based EC Techniques " Int. J. of Industrial Electronics and Drives, Inderscience Publishers., 2017 Vol.3, No.4, pp.229 - 237.

[6] Mohammed I. Mosaad, Ahmed Abu-Siada, Mohamed Elnaggar"Application of Superconductors to Improve the Performance of DFIG-based WECS" IEEE access journal, December 2019, Volume 7, Issue 1, pp103760-103769.

[7] Mohamed I. Mosaad, Ahmed Alenany, A. Abu-Siada 'Enhancing the Performance of Wind Energy Conversion Systems using Unified Power Flow Controller' IET, Generation, transmission and distribution journal, 2020, 10.1049/iet-gtd.2019.1112.

[8] Mohamed I. Mosaad "Direct Power Control of SRG based- Wind Energy Conversion Systems Using Optimised Fractional-Order PI Controller" IET Electric Power Applications, Source: Volume 14, Issue
3, March

2020, p. 409-417,DOI: $10.1049 /$ ietepa.2019.0194 DOI: 10.1049/iet-pa.2019.0194 .

[9] M. Bahy, Mohamed I. Mosaad, Mohamed G. Ashmawy and Essam M. Aboul-Zahab "Voltage Regulation of SRG Using Particle Swarm Optimization for Wind Turbine Applications" 17th International Middle- East Power Systems Conference -MEPCON'2015.

[10] M.M.El Metwally, A.A.El Emary, F.M.El Bendary and M.I.Mosaad "Optimal allocations of FACTS devices to enhance total transfer capability using evolutionary programming" in Proc. Power System Conference, 2008, MEPCON 2008, 12th International Middle -East, pp. 1-4.

[11] M.M.El Metwally, A.A.El Emary, F.M.El Bendary and M.I.Mosaad "Optimal allocations of FACTS devices to enhance total transfer capability using evolutionary programming" in Proc. Power System Conference, 2008, MEPCON 2008, 12th International Middle -East, pp. 1-4

[12] Mohamed I. Mosaad "Whale Optimization Algorithms-based PI controllers of STATCOM for Renewable Hybrid Power System" World journal of modelling and simulation, United Kingdom, Vol. 16 (2020) No. 1, pp. 26-40.

[13] Mohamed I. Mosaad, Mohamed G. Ashmawy "Short Term Load Forecasting Using Curve Fitting Prediction Optimized By Bacterial Foraging Optimization" International Review on Modelling and Simulations (IREMOS), Italy, Vol 6,no.3, August 2013, pp1150-1154.

\section{Creative Commons Attribution License 4.0 (Attribution 4.0 International, CC BY 4.0)}

This article is published under the terms of the Creative Commons Attribution License 4.0 https://creativecommons.org/licenses/by/4.0/deed.en_US 